\title{
EVALUASI PENGUKURAN KINERJA DENGAN PENDEKATAN BALANCE SCORECARD (Studi pada PT BNI (Persero), Tbk.)
}

\author{
Jana Sandra \\ Institut Ilmu Sosial dan Manajemen STIAMI \\ Email: jsandra46@gmail.com
}

ARTIICLE INFO ABSTRACT

Keywords:

Performance Measurement, Balance Scorecard

\begin{abstract}
This case study is a performance measurement system on BNI with PMS (performance measuring system) method is a Balance Scorecard based. Since 2006, BNI's performance measurement system uses only 2 perspectives, namely financial and operational, so it has not presented the comprehensive and integrative performance of the organization. However, starting in 2011, BNI performs Balance Scorecard based performance process using 6 (six) perspectives namely: financial, growth, risk, customer, employee and process. Performance measurement is conducted at 6 (six) level of organization that is: BNI wide, sectoral, division, region, branch and center while for office service and cash office level measurements are still in developmen process. With the development of six perspectives and measurement of all levels, it is expected that BNI performance measurement becomes more objective and linkage. BNI wide performance measurement results at the end of each year with a balanced scorecard approach is expected to be a strategic planning of the bank in determining the performance improvement of the current year so that the scorecard can be maximized.
\end{abstract}

\section{PENDAHULUAN}

Perusahaan adalah sebuah organisasi yang bertujuan untuk dapat menghasilkan kemakmuran bagi stakeholder dengan menggunakan sumber daya yang dimiliki secara benar. Di dalam era globalisasi dan persaingan usaha yang semakin tinggi maka para eksekutif perusahaan semakin mendapatkan tuntutan yang semakin berat yaitu tingginya harapan shareholder atas tingkat keuntungan.

Pengukuran kinerja merupakan salah satu faktor yang amat penting bagi sebuah perusahaan. Salah satunya untuk menilai keberhasilan perusahaan serta sebagai dasar penyusunan remunerasi pegawai, bahan evaluasi, dan sebagainya. Selama ini pengukuran secara tradisional hanya menitikberatkan pada aspek keuangan saja. Manajer yang berhasil mencapai tingkat keuntungan yang tinggi dinilai berhasil dan memperoleh imbalan yang baik dari perusahaan. Tetapi, menilai kinerja perusahaan semata-mata dari sisi keuangan akan dapat menyesatkan, karena kinerja keuangan yang baik saat ini dapat dicapai dengan mengorbankan kepentingan-kepentingan jangka panjang perusahaan. Sebaliknya, kinerja keuangan yang kurang baik dalam jangka pendek dapat terjadi karena perusahaan melakukan investasi-investasi demi kepentingan jangka panjang.

Balance Scorecard merupakan suatu kerangka kerja baru yang mengintegrasikan berbagai ukuran yang diturunkan dari strategi perusahaan. Selain ukuran finansial masa lalu, Balance Scorecard juga menggunakan pendorong kinerja masa depan. Balance Scorecard tetap mem pertahankan berbagai ukuran finansial tradisional yang hanya menjelaskan berbagai peristiwa masa lalu. Hal ini adalah tidak memadai untuk menuntun dan mengevaluasi perjalanan yang harus dilalui perusahaan abad informasi dalam menciptakan nilai masa depan melalui investasi yang ditanamkan pada pelanggan, pemasok, pekerja, proses, teknologi dan inovasi. Balance Scorecard melengkapi seperangkat ukuran finansial kinerja masa lalu dengan ukuran pendorong (drivers) kinerja masa depan. Banyak perusahaan yang mengklaim telah menerapkan Balance Scorecard. Padahal baru menerapkan model pengukuran yang relatif lebih seimbang ketimbang hanya menggunakan pengukuran kinerja yang berbasis pada ukuran keuangan semata. Keberhasilan penerapan Balance Scorecard sangat ditentukan oleh proses penyusunan pengembangan Balance Scorecard itu sendiri. Pengembangan Balance Scorecard yang tidak tepat pada akhirnya kembali mengantarkan perusahaan kepada model pengukuran yang tidak mampu menjelaskan strategi perusahaan. Atau dengan kata 
lain perusahaan menerapkan model pengukuran yang relatif berimbang saja atau bahkan hanya merupakan model pengukuran kinerja yang berbasis finansial belaka.

PT BNI (Persero), Tbk. memulai sebuah rencana kerja dari level BNI wide (corporate wide), yaitu corporate strategy yang dijadikan sebagai arah bisnis. Setelah itu, dijabarkan kembali dalam sebuah Rencana Kerja Akhir Perusahaan (RKAP), business plan, dan terakhir adalah pembagian alokasi target. PT BNI (Persero) telah melakukan proses pengukuran kinerja berbasis Balance Scorecard mulai 2011 dalam enam perspektif, yaitu financial, growth, risk, customer, employee dan process. Pengukuran kinerja saat ini dilakukan pada enam level organisasi yaitu BNI wide, sektoral, divisi, wilayah, cabang dan sentra. Sedangkan untuk level kantor layanan dan kantor kas masih dalam proses pengembangan. Setelah pada periode sebelumnya, sejak 2006 perseroan telah melakukan pengukuran kinerja dengan hanya dua perspektif yaitu financial dan operasional. Dengan pengembangan enam perspektif dan pengukuran seluruh level, diharapkan pengukuran kinerja menjadi lebih berimbang, lebih objektif dan linkage.

Dalam menghadapi tantangan di sektor perbankan yang semakin kompetitif, manajemen PT BNI (Persero), Tbk. mempunyai visi dan misi sebagai arah tujuan perusahaan. Untuk mencapai visi dan misi tersebut telah dirumuskan Rencana Jangka Panjang Perusahaan yang terbagi dalam tiga fase transformasi yaitu (1) unggul dalam layanan pada 2008; (2) unggul dalam layanan dan kinerja pada 2013; (3) dan menjadi bank kebanggaan nasional yang unggul dalam kinerja dan layanan pada 2018. Pada kenyataannya, sampai dengan saat ini keunggulan kinerja keuangan yang dicanangkan dalam Rencana Jangka Panjang Perusahaan belum terlihat tanda-tanda untuk terwujud. Hal ini terlihat dari kinerja perseroan sampai dengan Semester I/2012 bila dibandingkan dengan bank pesaing sebagaimana yang disajikan pada tabel 1. berikut:

Tabel 1. Peringkat 4 Bank Terbesar Indonesia Juni 2012

\begin{tabular}{|l|c|c|c|c|c|}
\hline \multicolumn{1}{|c|}{ Bank } & Aset & Kredit & DPK & Bunga & Laba \\
\hline Mandiri & 1 & 1 & 1 & 1 & 2 \\
\hline BRI & 2 & 2 & 2 & 2 & 1 \\
\hline BCA & 3 & 3 & 3 & 3 & 3 \\
\hline BNI & 4 & 4 & 4 & 4 & 4 \\
\hline
\end{tabular}

Sumber: www.bi.go.id (2013)

Dari tabel di atas terlihat bahwa dari lima indikator kinerja yang diukur terhadap empat bank terbesar di Indonesia, PT BNI (Persero), Tbk. berada pada peringkat terakhir. Peringkat ini secara konsisten terjadi sejak 2007, artinya sejak 5 tahun 6 bulan yang lalu perseroan belum mampu meningkatkan kinerja secara signifikan. Sebagai upaya untuk meningkatkan performance perseroan di tengah persaingan perbankan, PT BNI (Persero), Tbk. melakukan suatu proses transformasi bisnis yang disebut dengan program BNI Reformasi 1.0. Dengan berbagai proyek perbaikan secara komprehensif dan bertujuan untuk meningkatkan kemampuan perseroan dalam memberikan solusi kebutuhan perbankan secara holistik kepada para nasabah. Program BNI Reformasi 1.0 yang dilakukan sepanjang 2011 merupakan rangkaian program yang telah diinisiasi sejak kick off pada Desember 2009, dimana 2011 telah memasuki fase implementasi dan diharapkan selesai pada 2014.

Perbaikan yang dilakukan adalah transformasi bisnis yang sebelumnya lebih berorientasi pada product centric kini berubah ke arah customer centric. Beberapa inisiatif penting untuk mendukung transformasi ini di antaranya perbaikan business process, people and organization development, IT improvement, cost structure, Enterprise Risk Management (ERM), serta Planning and Budgeting (P\&B). Berbagai proyek yang dilakukan, tentu merubah proses bisnis secara keseluruhan, termasuk cara pengukuran kinerja. Oleh karena itu di dalam scope proyek P\&B pengukuran kinerja berbasis Balance Scorecard melakukan perubahan secara bertahap. Berdasarkan uraian tersebut penulis tertarik untuk melakukan penelitian terhadap implementasi Balance Scorecard dengan judul "Evaluasi Implementasi Balance Scorecard sebagai Sistem Pengukuran Kinerja PT BNI (Persero), Tbk".

Rumusan permasalahan yang akan diajukan dalam penelitian ini adalah:

1. Apakah pencapaian kinerja perusahaan sudah tercapai sesuai dengan pendekatan balance score card?

2. Apa saja faktor-faktor mendukung dan menghambat dalam pencapaian kinerja ditetapkan perusahaan?

3. Upaya apa saja yang harus dilakukan untuk meningkatkan pencapaian kinerja perusahaan? 


\section{KAJIAN PUSTAKA}

\section{a. Kegiatan Bank}

Sebagai lembaga keuangan yang berorientasi bisnis, bank juga melakukan berbagai kegiatan. Kegiatan bank sehari-hari tidak terlepas dari bidang keuangan. Kegiatan yang paling pokok adalah membeli uang dengan menghimpun dana dari masyarakat luas. Kemudian menjual uang yang berhasil dihimpun lalu menyalurkan kembali kepada masyarakat melalui pemberian pinjaman atau kredit. Dari Kegiatan jual beli uang inilah bank memperoleh keuntungan yaitu dari selisih harga beli (bunga simpanan) dengan harga jual (bunga pinjaman). Di samping itu kegiatan bank lainnya dalam rangka mendukung kegiatan menghimpun dan menyalurkan dana adalah memberikan jasa-jasa lainnya. Kegiatan ini ditujukan untuk memperlancar kegiatan menghimpun dan menyalurkan dana.

Dalam praktiknya kegiatan bank dibedakan sesuai dengan jenis bank tersebut. Setiap jenis bank memiliki ciri dan tugas tersendiri dalam melakukan kegiatan, misalnya dilihat dari segi fungsi bank yaitu antara kegiatan bank umum dengan kegiatan Bank Perkreditan Rakyat (BPR), jelas memiliki tugas atau kegiatan yang berbeda. Kegiatan bank umum lebih luas dari BPR, artinya produk yang ditawarkan oleh bank umum lebih beragam, hal ini disebabkan bank umum mempunyai kebebasan untuk menentukan produk dan jasa. Sedangkan BPR mempunyai keterbatasan tertentu sehingga kegiatan lebih sempit.

Untuk lebih jelas kegiatan masing-masing dapat dijelaskan masing-masing dari segi fungsi. Bank umum atau yang lebih dikenal dengan sebutan bank komersil merupakan bank yang paling banyak beredar di Indonesia. Bank umum juga memiliki berbagai keunggulan jika dibandingkan dengan BPR, baik dalam bidang ragam pelayanan maupun jangkauan wilayah operasional. Artinya bank umum memiliki kegiatan pemberian jasa yang paling lengkap dan dapat beroperasi diseluruh wilayah Indonesia. Dalam praktik ragam produk tergantung dari status bank yang bersangkutan. Menurut status bank umum dibagi ke dalam dua jenis, yaitu bank umum devisa dan bank umum non devisa. Masing-masing status memberikan pelayanan yang berbeda. Bank umum devisa misalnya memiliki jumlah layanan jasa yang paling lengkap seperti dapat melakukan kegiatan yang berhubungan dengan jasa luar negeri. Sedangkan bank umum non devisa sebaliknya tidak dapat melayani jasa yang berhubungan dengan luar negeri.

Kegiatan bank umum secara lengkap meliputi kegiatan sebagai berikut:

1. Menghimpun dana (funding), merupakan kegiatan membeli dana dari masyarakat, dikenal juga funding. Kegiatan ini dengan cara menawarkan berbagai jenis simpanan disebut juga nama rekening atau account dengan jenis:

a. Simpanan Giro (Demand Deposit), merupakan simpanan pada bank dengan penarikan dapat dilakukan menggunakan cek atau bilyet giro. Besarnya jasa giro tergantung dari bank yang bersangkutan.

b. Simpanan Tabungan (Saving Deposit), merupakan simpanan pada bank dengan penarikan sesuai persyaratan yang ditetapkan perbankan. Penarikan dilakukan menggunakan buku tabungan, slip penarikan, atau kartu Anjungan Tunai Mandiri (ATM).

c. Simpanan Deposito (Time Deposit), merupakan simpanan dan penarikan memiliki jangka waktu tertentu. Namun saat ini sudah ada bank yang memberikan fasilitas dengan penarikan dapat dilakukan setiap saat.

2. Menyalurkan dana (lending), merupakan kegiatan menjual dana yang berhasil dihimpun dari masyarakat. Penyaluran dana yang dilakukan oleh bank dilakukan melalui pemberian pinjaman yang lebih dikenal dengan nama kredit. Kredit yang diberikan oleh perbankan terdiri dari beragam jenis, tergantung dari kemampuan bank yang menyalurkan. Sebelum kredit dikucurkan, terlebih dulu menilai kelayakan kredit yang diajukan oleh nasabah. Secara umum jenis-jenis kredit yang ditawarkan meliputi kredit investasi, kredit modal kerja, kredit perdagangan, kredit produktif, kredit konsumtif, dan kredit profesi.

3. Memberikan jasa-jasa bank lainnya (services), merupakan kegiatan penunjang untuk mendukung kelancaran kegiatan menghimpun dan menyalurkan dana. Sekalipun sebagai kegiatan penunjang, kegiatan ini sangat banyak memberikan keuntungan bagi bank dan nasabah. Bahkan dewasa ini kegiatan ini memberikan kontribusi keuntungan yang tidak sedikit bagi keuntungan bank, apalagi keuntungan dari spread based semakin mengecil, bahkan cenderung negatif spread (bunga simpanan lebih besar dari bunga kredit). Semakin lengkap jasa-jasa bank yang dapat dilayani oleh suatu bank maka semakin baik. Kelengkapan ini ditentukan dari permodalan bank serta kesiapan bank dalam menyediakan SDM yang handal. Disamping juga perlu didukung kecanggihan teknologi. Jasa bank yang ditawarkan meliputi kiriman uang (transfer), kliring (clearing), inkaso (collection), safe deposit box, kartu kredit 
(bank card), bank notes, bank garansi, bank draft, letter of credit (L/C), cek wisata (travelers cheque), menerima setoran-setoran (pembayaran pajak, pembayaran telepon, pembayaran air, pembayaran listrik, pembayaran uang kuliah), melayani pembayaran (membayar gaji/pensiun/honorarium, pembayaran deviden pembayaran kupon, pembayaran bonus/hadiah), dan bermain di dalam pasar modal (penjamin emisi - underwriter, penjamin - guarantor, wali amanat - trustee, perantara perdagangan efek pialang/broker, pedagang efek - dealer, perusahaan pengelola dana - investment company).

\section{b. Strategi Bisnis}

Dunia bisnis yang terus berkembang dan lingkungan yang terus berubah mengharuskan para pemain bisnis untuk berpikir dan bertindak strategis guna dapat bertahan di dalamnya. Menurut Thompson et.al (2009), strategi diartikan sebagai rencana aksi pihak manajemen dalam rangka menjalankan bisnis dan melaksanakan operasional perusahaan. Sementara Hambrick dan Fredickson (2005) menggambarkan strategi dalam sebuah pola yang disebut strategy diamond yang merupakan bagian dari strategi bisnis, strategy diamond terdiri dari lima aspek utama, yaitu:

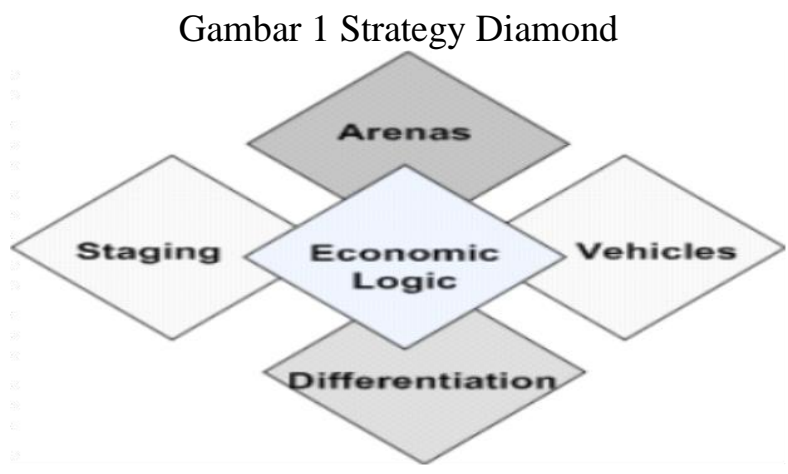

Sumber: http://sourcesofinsight.com

Arena (tempat), hal ini merupakan "tempat" dimana bisnis atau usaha tersebut akan berada, menyangkut wilayah, demografi serta segmen pasar dan kategori produk yang akan dijual. Pertanyaan utama yang perlu dijawab disini adalah "Where will we be active and with how much emphasis?" Lalu vehicle (sarana), merupakan sarana atau bagaimana cara perusahaan untuk dapat mencapai tujuan, baik dalam segmen pasar, kategori produk atau yang lainnya. Hal ini dapat dicapai dengan internal development maupun external development melalui aliansi strategic, akuisisi, merger dan lain-lain. Pertanyaan utama yang perlu dijawab disini adalah "How will we get there?"

Differentiators, berhubungan dengan keunggulan kompetitif yang dimiliki oleh perusahaan dan bisnis guna memenangkan kompetisi, hal ini dapat dilihat dari sisi brand, customization, price atau yang lainnya. Pertanyaan utama yang perlu dijawab disini adalah "How will we win?" Staging and pacing, merupakan penentuan atas rangkaian dan kecepatan langkah-langkah strategi yang akan dilakukan, hal ini menjadi penting guna mengidentifikasi langkah-langkah strategik karena kemungkinan-kemungkinan yang muncul dalam perjalanan tidak hanya satu namun tidak dapat diduga. Pertanyaan utama yang perlu dijawab disini adalah "What will be our speed and sequence of moves?"

Economic Logic (logika ekonomi dan bisnis) yang digunakan dalam perusahaan menghasilkan profit. Dalam perusahaan yang berorientasi profit hal ini dapat berbentuk skala ekonomi atau economic scope atau hal yang lainnya, economic logic dipandang sebagai aspek yang mempersatukan aspek-aspek telah disampaikan di atas ditambah dengan keinginan para stakeholder lain. Strategi bisnis berfokus pada peningkatan daya saing sebuah produk perusahaan/unit bisnis dalam suatu industri atau segmen pasar tertentu yang dilayani oleh perusahaan atau bisnis unit tersebut (Wheelen \& Hunger, 2002).

Strategi bisnis berhubungan dengan aksi dan pendekatan yang dibuat untuk menghasilkan sebuah kinerja sukses dalam usaha bisnis. Strategi bisnis dibuat para general manager (pemimpin divisi) masingmasing unit bisnis dengan memperhatikan masukan dari berbagai unit di bawahnya dengan tujuan untuk menjawab pertanyaan-pertanyaan klasik seperti: apakah bisnis inti perusahaan? Siapa saja para pelanggan bisnis kita? Hal apakah yang berharga bagi para pelanggan? Akan menjadi apakah bisnis/perusahaan kita ke depan? Serta bisnis apakah yang seharusnya kita jalankan? (Kotler \& Keller, 2009). Menurut Govindarajan dan Anthony (2004) strategi bisnis dibuat guna menghadapi situasi kompetisi antar perusahaan di dalam industri, biasanya memperhatikan dua aspek yang saling berhubungan yaitu (a) misi unit bisnis (tujuan yang 
ingin dicapai oleh unit bisnis tersebut) dan (b) keunggulan kompetitif yang dimiliki (bagaimana unit bisnis dapat berkompetisi dalam industri dalam rangka mencapai tujuan tadi).

\section{c. Pengukuran Kinerja}

Menurut Mulyadi (2001), pengukuran kinerja adalah penentuan secara periodik efektivitas operasional suatu organisasi, bagian organisasi dan karyawan berdasarkan sasaran, standar, dan kriteria yang telah ditetapkan sebelumnya. Organisasi pada dasarnya dijalankan oleh manusia, maka pengukuran kinerja sesungguhnya merupakan penilaian perilaku manusia dalam melaksanakan peran yang dimainkan dalam mencapai tujuan organisasi. Sedangkan menurut Anthony, Banker, Kaplan, dan Young (2006) pengukuran kinerja didefinisikan sebagai the activity of measuring the performance of an activity or the entire value chain. Dari kedua definisi tersebut dapat disimpulkan bahwa suatu sistem pengukuran kinerja diperlukan untuk mengetahui keberhasilan perusahaan dalam mencapai tujuan yang telah ditetapkan baik jangka panjang maupun jangka pendek.

Ada beberapa hal yang perlu menjadi perhatian dalam pengukuran kinerja, yaitu:

1. Plan: tujuan dan sasaran organisasi ditentukan berdasarkan rencana strategi yang berisi rencana kinerja yang telah disepakati sebelumnya.

2. Measure: tujuan dan sasaran organisasi dibangun untuk mengukur hasil bisnis yang penting. Begitu pula dengan kinerja organisasi juga akan diukur.

3. Act: menentukan aksi-aksi apa saja yang diperlukan untuk mencapai tujuan dan sasaran dari rencana kinerja.

4. Monitor: manajemen pengukuran kinerja merupakan proses terus-menerus yang terfokus pada feedback untuk memeriksa kemajuan dalam mencapai tujuan dan sasaran.

5. Review: perlu melakukan review secara teratur terhadap kemajuan dan pencapaian dalam pengukuran kinerja.

Menurut Mulyadi (2001), tujuan pokok pengukuran kinerja untuk memotivasi karyawan dalam pencapaian sasaran organisasi dan mematuhi standar perilaku yang telah ditetapkan, agar membuahkan hasil dan tindakan yang diinginkan. Sedangkan menurut Hansen dan Mowen (2007) pengukuran kinerja didesain untuk mendapat mengeliminasi aktivitas yang tidak bernilai tambah dan mengoptimasi aktivitas yang bernilai, sejalan perkembangan manajemen aktivitas.

Kriteria sistem pengukuran kinerja yang efektif menurut Noe (2003) terdiri dari beberapa aspek, yaitu (1) mempunyai keterkaitan yang strategis (strategic congruence); (2) validitas (validity) apabila hanya mengukur dan menilai aspek-aspek yang relevan dengan kinerja yang diharapkan; (3) reliabilitas (reliability) berkaitan dengan konsistensi pengukuran kinerja yang digunakan; (4) akseptabilitas (acceptability) dapat diterima oleh pihak-pihak yang menggunakan; dan (5) spesifisitas (specificity) dimana pengukuran kinerja yang diharapkan disampaikan kepada para pegawai sehingga memahami apa yang diharapkan dari mereka dan bagaimana cara untuk mencapai kinerja tersebut.

\section{d. Balance Scorecard}

Kaplan dan Norton (2006) menyatakan "the balance scorecard provides executives with a comprehensive framework that translates a company's vision and strategy into a coherent set of performance measures" Konsep Balance Scorecard (BS) diperkenalkan pertama kali oleh Robert S Kaplan dan David P Norton pada tahun 1992 yang melaporkan suatu metodologi penelitian kinerja yang berorientasi pada pandangan strategis ke masa depan. Menurut Kaplan dan Norton (2006) Balance Scorecard adalah suatu kerangka kerja baru untuk mengintegrasikan berbagai ukuran yang diturunkan dari strategi perusahaan. Balance Scorecard mencakup berbagai aktivitas penciptaan nilai yang dihasilkan oleh para partisipan perusahaan yang memiliki kemampuan motivasi tinggi, sementara tetap memperhatikan kinerja jangka pendek. Balance Scorecard dengan jelas mengungkapkan berbagai hal yang menjadi pendorong tercapai kinerja dan kompetitif jangka panjang.

Balanced Scorecard memiliki keistimewaan dalam hal cakupan pengukuran yang cukup komprehensif karena selain mempertimbangkan kinerja-kinerja non-financial. Empat perspektif yang membentuk kerangka Balanced Scorecard adalah:

1. Perspektif keuangan, menjadi fokus tujuan dan ukuran di semua perspektif scorecard lain. Tolok ukur kinerja keuangan menunjukkan apakah strategi perusahaan dan implementasi memberikan sumbangan kepada perbaikan laba perusahaan. Kaplan dan Norton (2006) mengidentifikasikan tiga tahapan dari siklus kehidupan bisnis, yaitu pertumbuhan (growth) sebagai tahap pertama dari siklus kehidupan bisnis; lanjut bertahan (sustain stage) tahap dimana perusahaan masih melakukan investasi dengan 
mempersyaratkan tingkat pengembalian yang terbaik; dan tahap menuai (harvest) merupakan kematangan (mature) dimana perusahaan melakukan panen terhadap investasi.

2. Perspektif customer, perusahaan melakukan identifikasi dan segmen pasar yang dimasuki, dimana perusahaan beroperasi dan kemudian mengukur kinerja berdasarkan target segmen tersebut. Ada dua kelompok pengukuran yang terikat, yaitu (a) customer care measurement (pengukuran inti) adalah seperangkat indikasi pengukuran yang terdiri atas lima tolak ukur yaitu market share, customer retention, customer acquisition, customer profitability, dan customer satisfaction. (b) customer value proposition (penilaian penunjang), adalah kelompok pemicu kinerja yang didasarkan pada atribut product/service attributes, customer relationship, dan image and reputation.

3. Perspektif proses bisnis internal, mengidentifikasi proses internal bisnis yang kritis dan diunggulkan perusahaan. Pendekatan Balanced Scorecard dalam pengukuran perspektif secara umum dapat dibagi menjadi tiga tahap (Kaplan dan Norton, 2006), yaitu proses inovasi, proses operasi, dan proses pelayanan purna jual.

4. Perspektif pembelajaran dan pertumbuhan, menyediakan infrastruktur yang memungkinkan tujuan ambisius dalam tiga perspektif lain agar dapat dicapai. Harus dibangun dalam menciptakan pertumbuhan dan peningkatan kinerja jangka panjang melalui tiga kategori utama (Kaplan 2006), yaitu kapabilitas pekerja, kapabilitas sistem informasi, serta motivasi, pemberdayaan, dan keselarasan.

\section{METODOLOGI PENELITIAN}

Jenis penelitian yang digunakan adalah studi kasus dan deskriptif kuantitatif. Metode deskriptif ini terbentuk dari hubungan antara variabel yang terdapat dalam suatu penelitian. Pendekatan studi kasus dan deskriptif kuantitatif dipilih karena pengukuran kinerja Performance Management System (PMS) unit berdasarkan pendekatan Balance Scorecard dengan pendekatan enam perspektif sehingga perlu dilakukan guna mendapatkan gambaran yang jelas situasi yang terjadi di dalamnya. Selain itu posisi peneliti sendiri berada di dalam lingkungan alami tersebut memudahkan dalam pengamatan langsung serta mendapatkan data yang dibutuhkan dalam penelitian.

Jenis data yang digunakan dalam penelitian ini mencakup data primer dan sekunder, baik bersifat kualitatif maupun kuantitatif. Data primer didapatkan melalui observasi lapang, wawancara, dan kuesioner. Observasi lapang dilakukan untuk mendapatkan data dan informasi mengenai gambaran umum perusahaan dan struktur organisasi. Wawancara dilakukan dengan pihak perusahaan yang memiliki peranan yang besar dalam pengambilan keputusan. Responden yang dipilih adalah pihak internal dan eksternal perusahaan. Data primer dapat dikelompokkan: (1) documentation berupa struktur organisasi PT BNI (Persero), Tbk. atau standar operasional prosedur pengukuran kinerja (BPP on line), data PMS 2010 dan 2012, laporan keuangan 2011 dan 2012, corporate strategy pada 2011 dan 2012, strategi inisiatif BNI wide dan masing-masing unit, dan lain sebagainya. (2) Archival records berupa data dari masing-masing perspektif baik data otomasi (system) maupun manual seperti financial, growth, risk, customer, employee, dan process.

Sementara data sekunder diperoleh dari studi literatur melalui buku, skripsi, data perusahaan, internet dan data publikasi lainnya. Pengumpulan data dilakukan melalui teknik wawancara dilakukan dengan wawancara kepada pihak-pihak terkait dalam perusahaan seperti Kepala Cabang, Manajer, dan Karyawan. Kepala cabang dan manajer dianggap memiliki peranan besar dalam pengambilan keputusan dan mengetahui kondisi perusahaan secara menyeluruh. Metode penarikan narasumber untuk wawancara menggunakan teknik pengambilan purposive sampling. Teknik kepustakaan dengan mendapatkan informasi melalui membaca, mengutip dari berbagai buku, skripsi, internet dan data perusahaan.

Setelah semua data yang diperlukan dan relevan terkumpul sesuai dengan metode di atas, kemudian melakukan analisis terhadap data tersebut dengan:

a. Mengumpulkan data yang diperoleh melalui studi pustaka dan studi lapangan, dibaca dan ditelaah kembali secara seksama kemudian data tersebut dibagi menjadi tiga tahapan sesuai dengan yang disebutkan oleh Faulkner (1995), Child \& Faulkner (1998) dan Buchel et.al (1998).

b. Tahap formasi dan operasi laporan PMS unit dilakukan content analysis guna mendapatkan deskripsi dan gambaran lengkap tentang pengukuran kinerja pada semua level organisasi.

c. Tahapan evaluasi dilakukan dengan analisis komparasi antara penerapan PMS yaitu enam perspektif yang dilaksanakan sejak 2011-2012 dengan penerapan PMS dua perspektif yaitu perspektif finansial dan operasional yang digunakan sejak 2006 hingga 2010.

d. Dari hasil yang didapat kemudian dibuat kesimpulan tentang berhasil atau tidaknya penerapan ukuran kinerja PMS dengan pendekatan Balance Scorecard untuk ikut mengukur kinerja pada semua unit dan 
pada akhirnya berperan serta ikut mendorong kinerja perseroan secara keseluruhan. Kemudian memberikan rekomendasi untuk kelanjutan perbaikan penerapan pengukuran kinerja PMS ke masa datang.

e. Laporan yang dihasilkan kemudian diberikan kepada perseroan untuk diperiksa kembali dengan tujuan menghilangkan kesalahan yang mungkin ada selain itu juga untuk menambah informasi baru serta menghilangkan bahan atau informasi yang bersifat rahasia bagi bank.

BSC menggunakan empat perspektif di dalam mengukur kinerja perusahaan, yaitu keuangan, pelanggan, proses bisnis internal, dan pertumbuhan dan pembelajaran. Sedangkan PT BNI (Persero), Tbk. menggunakan enam perspektif di dalam mengukur kinerja di seluruh level unit yaitu financial, growth, risk, customer, employee, dan process.

1. Perspektif financial diukur berdasarkan elemen-elemen profit and loss.

2. Perspektif growth sesuai dengan dua corporate strategy yaitu penajaman fokus portofolio bisnis pada segmen business banking dan consumer and retail banking serta pertumbuhan dana murah yang lebih yang agresif.

3. Perspektif risk karena di dalam usaha perbankan resiko bisnis nasabah sangat mungkin terjadi, khususnya dalam menyalurkan kredit, prinsip kehati-hatian termasuk dari sasaran strategik. Salah satunya pengkategorian debitur berdasarkan prinsip 5C (characteristic, capacity, capital, condition of economic, dan collateral).

4. Perspektif customer merupakan salah satu yang terpenting dalam perusahaan jasa seperti perbankan. Yaitu, memberikan layanan prima dan solusi yang bernilai tambah kepada seluruh nasabah, dan selaku mitra pilihan utama (the bank of choice). Untuk mendukung misi tersebut, perusahaan tidak lupa selalu memasukkan ke dalam corporate strategy tahunan yaitu perbaikan customer experience.

5. Perspektif employee, tidak dapat dipungkiri bahwa dukungan karyawan dalam pelaksanaan pekerjaan yang baik mampu mendukung pencapaian visi dan misi perusahaan.

6. Perspektif process, dimana perseroan ingin melakukan pengukuran strategi dari sisi internal perusahaan, dengan semakin baik sebuah proses bisnis internal berdampak kepada finansial dengan meningkatnya efisiensi.

\section{HASIL DAN PEMBAHASAN}

\section{a. Profil Perusahaan}

Berdiri sejak 1946, PT BNI (Persero), Tbk. dulu dikenal sebagai Bank Negara Indonesia merupakan bank pertama yang didirikan dan dimiliki oleh pemerintah Indonesia. Perseroan ini mulai mengedarkan alat pembayaran resmi pertama yang dikeluarkan pemerintah Indonesia, yakni ORI atau Oeang Republik Indonesia pada malam menjelang tanggal 30 Oktober 1946. Hingga kini, tanggal tersebut diperingati sebagai Hari Keuangan Nasional, sementara hari pendirian yang jatuh pada tanggal 5 Juli ditetapkan sebagai Hari Bank Nasional. Menyusul penunjukan De Javsche, bank yang merupakan warisan Belanda, pemerintah Indonesia membatasi peranan sebagai bank sirkulasi atau bank sentral. BNI lalu ditetapkan sebagai bank pembangunan, kemudian diberikan hak untuk bertindak sebagai bank devisa, dengan akses langsung untuk transaksi luar negeri.

Sehubungan dengan penambahan modal pada 1955, status perseroan diubah menjadi bank komersial milik pemerintah. Perubahan ini melandasi pelayanan yang lebih baik dan tuas bagi sektor usaha nasional. Sejalan dengan keputusan penggunaan tahun pendirian sebagai bagian dari identitas perusahaan, nama Bank Negara Indonesia 1946 resmi digunakan mulai akhir 1968. Perubahan ini menjadikan Bank Negara Indonesia lebih dikenal sebagai 'BNI 46'. Pada 1992, status hukum dan nama BNI berubah menjadi PT Bank Negara Indonesia (Persero). Sementara keputusan untuk menjadi perusahaan publik diwujudkan melalui penawaran saham perdana di pasar modal pada 1996. Kemampuan PT BNI (Persero), Tbk. untuk beradaptasi terhadap perubahan dan kemajuan lingkungan, sosial-budaya serta teknologi dicerminkan melalui penyempurnaan identitas perusahaan yang berkelanjutan dari masa ke masa. Hal ini juga menegaskan dedikasi dan komitmen PT BNI (Persero), Tbk. terhadap perbaikan kualitas kinerja.

Pada 2004, identitas perusahaan yang diperbaharui mulai digunakan untuk menggambarkan prospek masa depan yang lebih baik, setelah keberhasilan mengarungi masa-masa yang sulit. Berangkat dari semangat perjuangan yang berakar pada sejarah, PT BNI (Persero), Tbk. bertekad untuk memberikan pelayanan yang terbaik bagi negeri, serta senantiasa menjadi kebanggaan negara. Saat ini, perseroan menjadi bank terbesar ke-4 di Indonesia berdasarkan total aset, total kredit maupun total dana pihak ketiga. Kapabilitas BNI untuk menyediakan layanan jasa keuangan secara menyeluruh didukung oleh perusahaan 
anak di bidang perbankan syariah (Bank BNI Syariah), pembiayaan konsumer (BNI Multi Finance), pasar modal (BNI Securities), dan asuransi (BNI Life Insurance). Dengan total aset senilai Rp 299,1 triliun dan lebih dari 23.639 karyawan pada akhir 2011, PT BNI (Persero), Tbk. mengoperasikan jaringan pelayanan yang luas mencakup 1.364 outlet domestik dan 5 cabang luar negeri di New York, London, Tokyo, Hong Kong dan Singapura, 6.227 unit ATM milik sendiri, serta fasilitas internet banking dan SMS banking yang memberikan kemudahan akses bagi nasabah.

Visi adalah menjadi bank kebanggaan nasional yang unggul, terkemuka dan terdepan dalam layanan dan kinerja.

Misi adalah:

a. Memberikan layanan prima dan solusi yang bernilai tambah kepada seluruh nasabah, dan selaku mitra pilihan utama (the bank of choice).

b. Meningkatkan nilai investasi yang unggul bagi investor.

c. Menciptakan kondisi terbaik sebagai tempat kebanggaan untuk berkarya dan berprestasi.

d. Meningkatkan kepedulian dan tanggung jawab terhadap lingkungan sosial.

e. Menjadi acuan pelaksanaan kepatuhan dan tata kelola perusahaan yang baik.

Nilai yang ditanamkan adalah rasa nyaman dan rasa puas baik terhadap nasabah maupun dari segenap pegawai yang bekerja untuk perusahaan. Budaya kerja perusahaan PT BNI (Persero), Tbk. merupakan tuntunan perilaku insan yang terdiri dari profesionalisme, integritas, orientasi pelanggan, dan perbaikan tiada henti. Adapun enam nilai perilaku utama insan PT BNI (Persero), Tbk. adalah (1) meningkatkan kompetensi dan memberikan hasil terbaik; (2) jujur, tulus, dan ikhlas; (3) disiplin, konsisten, dan bertanggungjawab; (4) memberikan layanan terbaik melalui kemitraan yang sinergis; (5) senantiasa melakukan penyempurnaan; dan (6) kreatif dan inovatif.

Adapun struktur organisasi PT BNI (Persero), Tbk. dapat dilihat pada Gambar 2. Gambar 2. Struktur Organisasi PT BNI (Persero) Tbk.

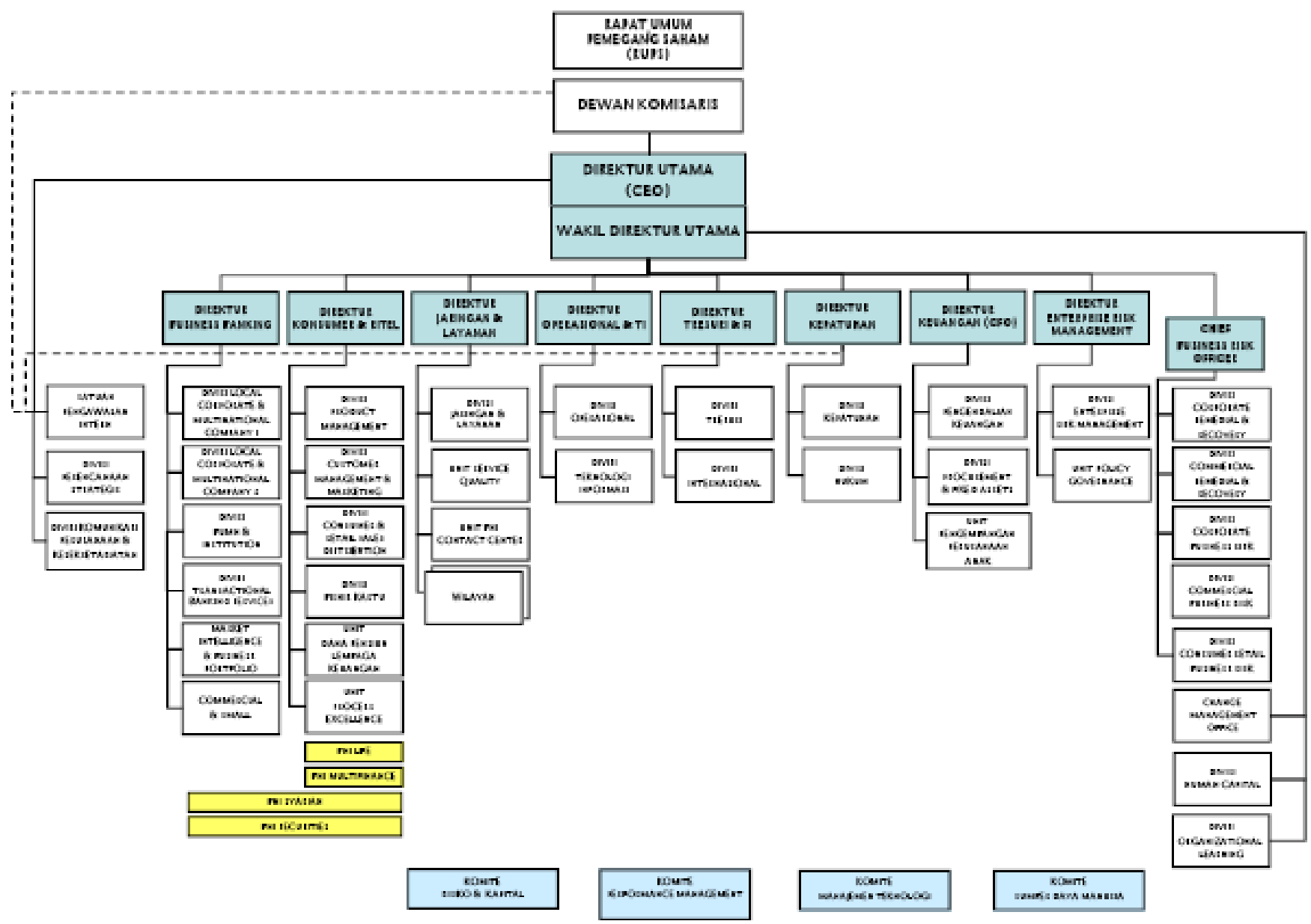

Dari gambar di atas, PT BNI (Persero), Tbk. melalui Wakil Direktur Utama yang membawahi Change Management Office (CMO) bertindak sebagai administrator PMS dibantu empat divisi lain yaitu Divisi 
Pengendalian Keuangan (PKU), Satuan Pengawasan Internal (SPI), Divisi Perencanaan Strategis (REN), dan Divisi Sumber Daya Manusia (SDM) sebagai Team Reviewer Kinerja PMS.

Adapun beberapa jenis produk keuangan dapat dibedakan sebagai berikut:

a. Taplus Utama, merupakan simpanan masyarakat secara perorangan dalam bentuk valuta rupiah yang transaksi penyetoran dan penarikan dapat dilakukan setiap saat melalui teller dan fasilitas melalui ATM maupun phone plus.

b. Taplus Muda, sebagai produk simpanan dalam bentuk tabungan yang merupakan turunan dari BNI Taplus dan diperuntukkan bagi kaum muda dengan usia mulai dari 15 sampai dengan 25 tahun.

c. Taplus Anak, merupakan tabungan yang diperuntukkan bagi anak-anak yang berusia di bawah 17 tahun.

d. BNI Tapenas, yaitu simpanan berjangka untuk investasi dana pendidikan anak dengan manfaat asuransi yang diperuntukkan bagi nasabah perorangan.

e. BNI Dollar, adalah simpanan dalam mata uang dollar yang memiliki nilai tukar lebih stabil dan aman dari risiko turunnya nilai rupiah serta memberi kemudahan dalam bertransaksi.

f. BNI Haji merupakan sarana pas untuk mendapatkan kepastian porsi keberangkatan menunaikan ibadah haji sesuai keinginan dalam masa keberangkatan tertentu.

g. BNI Giro adalah produk simpanan yang dapat ditarik kapan saja. Penarikan dapat menggunakan cek dan giro, surat perintah pembayaran atau pemindah bukuan, jenisnya dapat berupa rupiah dan valuta asing.

h. BNI Simponi (Simpanan BNI) adalah layanan program pensiun yang diselenggarakan oleh Dana Pensiun Lembaga Keuangan PT BNI (Persero), Tbk. dan bisa diikuti oleh semua lapisan masyarakat apapun profesinya, baik sebagai pegawai negeri, karyawan BUMN / BUMD, perusahaan swasta ataupun yang berprofesi sebagai notaris, akuntan, dokter, pedagang, konsultan, petani maupun mahasiswa dan sebagainya.

\section{b. Analisis Hasil}

KPI-KPI yang digunakan perspektif financial adalah lima indikator pengukuran yang tercantum berikut ini:

Tabel 2. Score Perspektif Financial

\begin{tabular}{|l|l|l|l|l|l|}
\hline \multicolumn{2}{|l|}{ Strategy Objectives } & KPI & Target & Realisasi & Score \\
\hline Financial Perspective & Earning After Tax & $7200 \mathrm{M}$ & $7104 \mathrm{M}$ & 3,61 \\
\hline F1 & Increase Profit & NPL Gross & $3,5 \%$ & $2,7 \%$ & 4,55 \\
\hline F2 & Reduce NPL & \% of OPEX Growth & $10,44 \%$ & $12,51 \%$ & 5,00 \\
\hline F3 & Manage Overhead Cost Efficiently & \% of NII Growth & $13,17 \%$ & $16,85 \%$ & 5,00 \\
\hline F4 & Optimize NII & \% of FBI Growth & $49,9 \%$ & $23,4 \%$ & 0,66 \\
\hline F5 & Increase Fee Base Income & & & 3,76 \\
\hline
\end{tabular}

Sumber: Data PMS BNI (2012)

Dari tabel di atas, terlihat bahwa pada perspektif financial menggunakan lima indikator pengukuran yaitu Earning After Tax, NPL Gross, \% of OPEX Growth, \% of NII Growth dan \% of FBI Growth. Berdasarkan hasil realisasi dari masing-masing KPI, diketahui rata-rata skor perspektif ini sebesar 3,76, dimana score tertinggi adalah 5 yang diperoleh KPI: \% of OPEX Growth dan \% of NII Growth. Pencapaian KPI \% of OPEX Growth dikarenakan keberhasilan penerapan strategi efisiensi untuk menekan berbagai cost, terutama variabel cost, seperti biaya promosi dan iklan. Untuk pencapaian KPI \% of NII Growth karena keberhasilan upaya peningkatan komposisi dana murah yang menekan cost of fund yang pada akhirnya berakibat pada tingginya pencapaian NII. Sedangkan score terendah diperoleh KPI Increase Fee Base Income, dimana salah satu penyebab ketidakberhasilan pencapaian target KPI ini dikarenakan fee base income yang berasal dari bank garansi yang menjadi unggulan, gagal memenuhi harapan.

Pada perspektif growth, terdapat empat KPI yang dijadikan pengukuran kinerja yaitu: 
Tabel 3. Score Perspektif Growth

\begin{tabular}{|c|c|c|c|c|c|}
\hline \multicolumn{6}{|c|}{ Strategy Objectives } \\
\hline \multicolumn{2}{|c|}{ Growth Perspective } & KPI & Target & Realisasi & Score \\
\hline G1 & $\begin{array}{l}\text { Increase Asset with Better Quality } \\
\text { \& Profitable }\end{array}$ & $\%$ of Asset Growth & $12,7 \%$ & $12,5 \%$ & 4,50 \\
\hline $\mathrm{G} 2$ & Optimize Customer Transaction & $\%$ of Customer Trx Growth & $20 \%$ & $17,5 \%$ & 3,32 \\
\hline G3 & Optimize Low Cost Fund Portfolio & $\%$ of CASA Growth & $17,1 \%$ & $17,8 \%$ & 5,00 \\
\hline G4 & - Sinergy BB \& CR & Product Holding Ratio & $1.1 \%$ & $1,09 \%$ & 4,87 \\
\hline & $\begin{array}{l}\text { - Sinergy BNI Incorporate } \\
\text { Score Rata-rata }\end{array}$ & $\begin{array}{l}\text { Growth Sinergies with } \\
\text { Subsidiareis }\end{array}$ & $10 \%$ & $-5,00 \%$ & $\begin{array}{l}-1,00 \\
3,34\end{array}$ \\
\hline
\end{tabular}

Sumber: Data PMS BNI (2012)

Dari tabel di atas, terdapat score minus yang diperoleh dari KPI Growth Synergies with Subsidiaries memperoleh score minus. Dalam hal ini, anak perusahaan yang diharapkan memberi kontribusi sebesar 10\% ternyata menderita kerugian secara keseluruhan sebesar 5\%, salah satu anak perusahaan sebagai penyumbang kerugian tersebut adalah BNI Life. Sedangkan untuk KPI \% of CASA Growth berhasil mencapai target, dimana strategi manajemen dengan cara mengurangi komposisi dana mahal dengan cara melepas ke market berdampak kepada rendahnya interest expense yang harus ditanggung oleh bank. Hal ini berdampak langsung kepada meningkatnya profit and loss PT BNI (Persero), Tbk.

Perspektif berikutnya adalah Risk, dimana hanya terdapat dua fokus utama perusahaan terhadap perspektif ini yaitu Indicator GCG dan \% of Composition of The Main Industri Financing sebagaimana yang terdapat pada Tabel 4 berikut:

Tabel 4. Score Perspektif Risk

\begin{tabular}{|c|c|c|c|c|c|}
\hline \multicolumn{6}{|c|}{ Strategy Objectives } \\
\hline Risk & Perspective & KPI & Target & $\begin{array}{l}\text { Realisas } \\
\text { i }\end{array}$ & $\begin{array}{l}\text { Scor } \\
\text { e }\end{array}$ \\
\hline $\mathrm{R} 1$ & $\begin{array}{ccc}\text { - } & \text { Enhance } & \text { Risk } \\
\text { Management \& GCG } & \end{array}$ & Indicator of GCG & 5 & 5 & 5 \\
\hline & $\begin{array}{l}\text { - Enhance Portfolio } \\
\text { Monitoring } \\
\text { Rata-rata Score }\end{array}$ & $\begin{array}{l}\% \text { of Composition of The } \\
\text { Main Industry Financing }\end{array}$ & $70 \%$ & $65 \%$ & $\begin{array}{l}4,02 \\
4,51\end{array}$ \\
\hline
\end{tabular}

Dari uraian data di atas dapat diartikan dari sisi penerapan Good Corporate Governance, PT BNI (Persero), Tbk. telah memiliki rambu-rambu yang telah diterapkan dengan baik. Dengan mengikuti segala regulasi yang ada, baik dari Bank Indonesia dan pemerintah (Kementerian BUMN, Kementerian Keuangan, dan lain-lain). Kemudian dituangkan dalam rencana kerja perusahaan hingga Pedoman Kerja Perusahaan, segala bentuk resiko seperti resiko pasar, hukum, keuangan dan lain sebagainya, dapat dimitigasi dengan baik dan benar. Sedangkan pada KPI \% of Composition of The Main Industry Financing, PT BNI (Persero), Tbk. harus lebih berhati-hati dalam menyalurkan kredit, karena industri-industri utama tersebut mendominasi hampir 70\% dari total aset. Industri-industri utama yang dimaksud antara lain industri oil and gas, pertambangan, infrastruktur, dan lain sebagainya. Dengan besarnya komposisi ini, menjadikan perseroan sangat rentan apabila salah satu atau beberapa debitur gagal memenuhi kewajiban.

Salah satu corporate strategy PT BNI (Persero), Tbk. yaitu meningkatkan customer experience dicoba untuk dijabarkan lebih detail ke dalam perspektif customer. Pada perspektif customer terdapat empat KPI, dua diantaranya memiliki score yang sempurna yaitu \% of BB Customer Growth dan \% of CR Customer Growth. Hal ini tidak lepas dari peran strategi value chain yang mulai dijalankan terutama untuk segmen Business Banking (BB) dan Customer Retail (CR), ditambah lagi dua segmen besar ini memiliki KPI yang sama di unit masing-masing yaitu Product Holding Ratio (PHR) untuk mengukur berapa banyak jenis produk yang dimiliki oleh setiap nasabah baik BB dan CR. Data keseluruhan KPI perspektif customer diuraikan pada Tabel 5 berikut: 
Tabel 5. Score Perspektif Customer

\begin{tabular}{|c|c|c|c|c|c|}
\hline \multicolumn{6}{|c|}{ Strategy Objectives } \\
\hline \multicolumn{2}{|c|}{ Customer Perspective } & KPI & Target & Realisasi & Score \\
\hline \multirow[t]{2}{*}{$\mathrm{C} 1$} & $\begin{array}{l}\text { Deepen Relationship to } \\
\text { Increase BB Customer by } \\
\text { Value Chain }\end{array}$ & $\%$ of BB Customer Growth & $10 \%$ & $11,30 \%$ & 5,00 \\
\hline & & $\begin{array}{l}\% \text { of Realization of Value } \\
\text { Chain }\end{array}$ & $80 \%$ & $65,03 \%$ & 3,12 \\
\hline $\mathrm{C} 1$ & $\begin{array}{ll}\text { Enhance } & \text { Customer } \\
\text { Engagement } & \end{array}$ & $\begin{array}{lll}\text { Customer } & \text { Out } & \text { from } \\
\text { Customer Last } & \text { Year } & \end{array}$ & $6 \%$ & $6,75 \%$ & 4,09 \\
\hline $\mathrm{C} 1$ & $\begin{array}{l}\text { Increase Number of CR } \\
\text { Customer } \\
\text { Rata-rata Score }\end{array}$ & $\%$ of CR Customer Growth & $10 \%$ & $12,12 \%$ & $\begin{array}{l}5,00 \\
4,30\end{array}$ \\
\hline
\end{tabular}

Sumber: Data PMS BNI (2012)

Tabel di atas, dapat dilihat bahwa terdapat KPI yang tidak terlalu baik skornya yaitu KPI \% of Realization of Value Chain, alasan dibalik pencapaian ini adalah program value chain baru full implementation pada 2012, sehingga hasil sinergi antara Sektor BB dan CR belum memperlihatkan hasil yang maksimal.

Pentingnya pegawai bagi perusahaan diperlihatkan dari Perspektif Employee berikut:

Tabel 6. Score Perspektif Employee

\begin{tabular}{|c|c|c|c|c|c|}
\hline \multicolumn{6}{|c|}{ Strategy Objectives } \\
\hline Em & oyee Perspective & KPI & Target & Realisasi & Score \\
\hline E1 & $\begin{array}{l}\text { Incease } \\
\text { Productivity }\end{array}$ & Earning Per Employee & $320 \mathrm{Jt}$ & $350 \mathrm{Jt}$ & 4,50 \\
\hline E2 & Enhance Selling Culture & $\begin{array}{l}\text { Realization of Selling Culture } \\
\text { Project }\end{array}$ & $100 \%$ & $98,00 \%$ & 4,44 \\
\hline E3 & Increase HR Capability & Trainning Realization & $100 \%$ & $99,17 \%$ & 4,89 \\
\hline E4 & $\begin{array}{ll}\text { Conductive } & \text { Working } \\
\text { Climate } & \\
\text { Rata-rata Score } & \end{array}$ & Employee Engagement Survey & $67 \%$ & $48,77 \%$ & $\begin{array}{l}3,12 \\
4,23\end{array}$ \\
\hline
\end{tabular}

Sumber: Data PMS BNI (2012)

Dengan rata-rata score sebesar 4,23 memperlihatkan bahwa produktifitas dan engagement pegawai terhadap perusahaan sudah memuaskan. Hanya KPI Employee Engagement Survey yang memperoleh score 3,12, hal ini dikarenakan hasil survei yang digunakan merupakan survei 2011 dimana inilah pengalaman pertama bagi Divisi Human Capital Taskforce (HCT) melakukan survei terhadap tingkat kepuasan pegawai dengan melibatkan responden seluruh pegawai Bank BNI (populasi). Sebagai informasi survei ini dilakukan setiap dua tahunan.

Sebuah proses yang baik berdampak kepada peningkatan kinerja financial dan non-financial. Pada perspektif process terdapat 11 indikator untuk pengukuran kinerja, beberapa di antara telah memperlihatkan keberhasilan seperti pada KPI Recovery Target dan \% of Electronic Transaction Channel dengan score masing-masing 5 dan 4,76. Dengan dibentuknya unit khusus untuk menangani credit recovery dan remedial recovery yaitu Divisi Remedial and Recovery Corporate (RRC) dan Remedial and Recovery Commercial and Small (RRM), kualitas kredit menjadi lebih baik. Demikian juga proses penagihan terhadap kredit-kredit yang telah dihapus buku juga lebih tertangani dengan lebih maksimal. Rekap KPI detail dapat diperlihatkan pada Tabel 7 berikut: 
Tabel 7. Score Perspektif Process

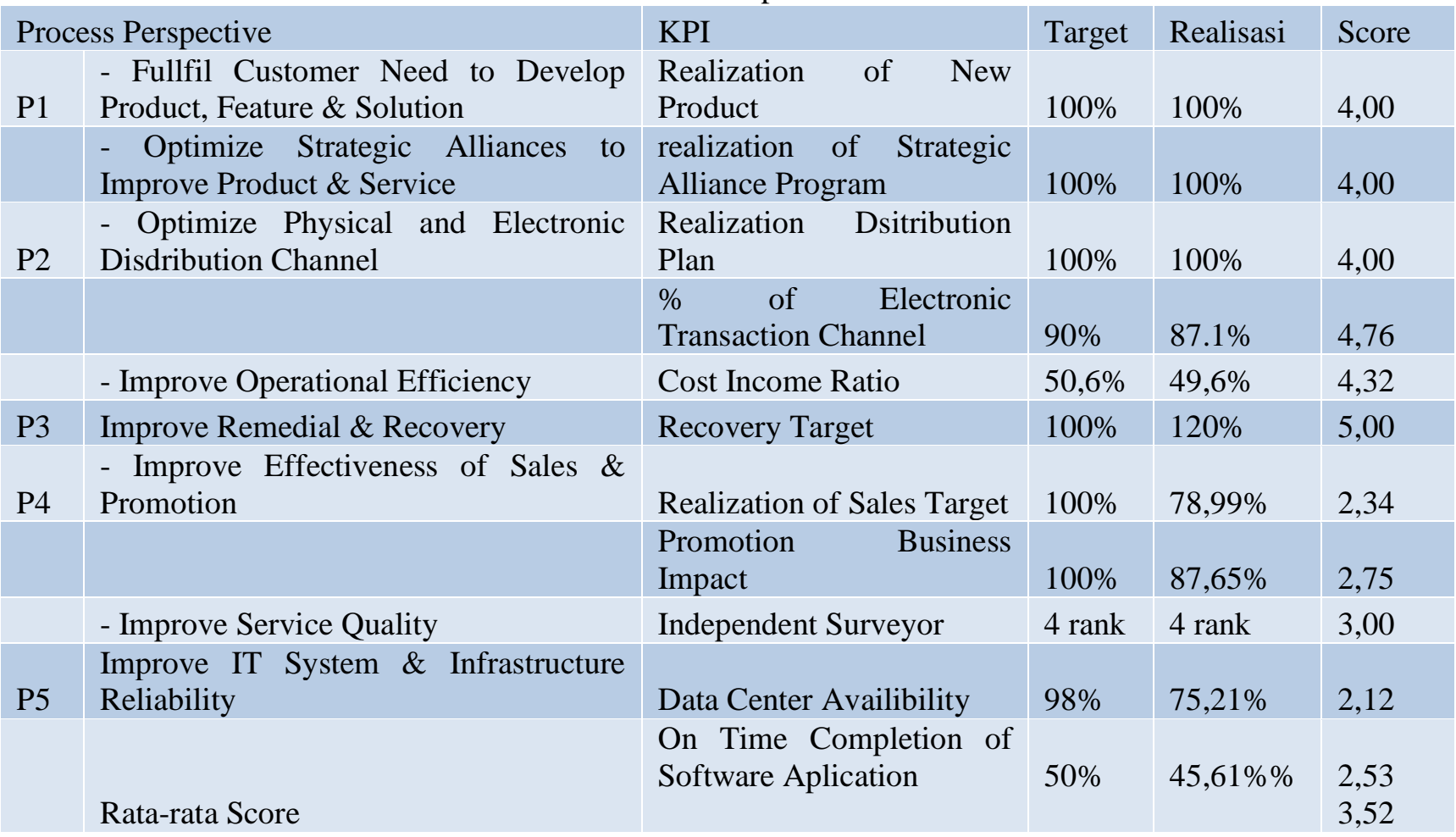

Sumber: Data PMS BNI (2012)

KPI-KPI yang belum menunjukkan performance terbaik dalam perspektif process antara lain Data Center Availability, On Time Completion of Software Application, Realization of Sales Target, dan Promotion Business Impact. Khusus untuk KPI Data Center Availability dan On Time Completion of Software Application tidak tercapai target yang telah ditetapkan dikarenakan belum berjalannya proyekproyek yang menangani IT system dan infrastruktur, yaitu proyek Integrated Data Management (IDM) dan Enterprise Data Warehouse (WDWH) dengan maksimal, karena kapabilitas SDM dan keterlambatan pemenuhan perangkat lunak. Sedangkan KPI Realization of Sales Target yang hanya memperoleh skor 2,34, dikarenakan pemenuhan tenaga sales yang tidak tepat waktu baik sales farmer dan hunter. Hal ini dapat dimaklumi, untuk mendapatkan tenaga sales yang mampu menjual semua produk perusahaan sangat sulit, sehingga pemenuhan capability dengan cara meningkatkan pengetahuan akan product knowledge, diharapkan dapat segera membantu meningkatkan skill dari para sales. Selain itu, ketidakjelasan KPI Individu di masing-masing tenaga sales, menyebabkan target sales menjadi tidak fokus dan terarah. Pada KPI Promotion Business Impact, penyebab kegagalan dalam pencapaian kinerjanya dikarenakan banyak dari aktifitas promosi yang belum dapat diklasifikasikan ke area bisnis secara langsung. Promosi dapat saja digunakan oleh segmen BB, CR, BNI wide dan lain sebagainya. Demikian juga, sebuah kegiatan promosi seringkali dilakukan oleh beberapa produk dan beberapa segmen.

Dari score akhir dari masing-masing perspektif diperoleh score akhir PT BNI (Persero), Tbk. yang diuraikan pada tabel berikut:

Tabel 8. Score Akhir BNI

\begin{tabular}{|llll}
\hline Perspektif & Score & Bobot & Score Tertimbang \\
\hline Perspektif Financial & 3.76 & 35 & 1.32 \\
\hline Perspektif Growth & 3.34 & 20 & 0.67 \\
Perspektif Risk & 4.52 & 10 & 0.45 \\
\hline Perspektif Customer & 4.30 & 10 & 0.43 \\
\hline Perspektif Employee & 4.23 & 15 & 0.63 \\
\hline Perspektif Process & 3.52 & 10 & 0.35 \\
\hline SCORE AKHIR BNI & & & 3.85 \\
\hline
\end{tabular}

Sumber: Data PMS BNI (2012) 
Secara garis besar score BNI menunjukkan angka 3,85. Artinya PT BNI (Persero), Tbk. berhasil mencapai target baik dari sisi finansial maupun non finansial. Skor tertinggi pada perspektif risk, kemudian diikuti customer, employee, financial, process, dan terakhir adalah growth. Dengan kondisi ini manajemen mendapat gambaran terhadap kinerja BNI secara keseluruhan, dimana hal ini dapat dijadikan bahan evaluasi dan perbaikan untuk tahun-tahun mendatang.

Terdapat beberapa faktor pendukung dalam pengukuran kinerja di PT BNI (Persero), Tbk. antara lain PMS yang merupakan bagian dari proyek planning and budgeting yang mempunyai fungsi untuk melakukan pengawasan terhadap kinerja bisnis PT BNI (Persero), Tbk. (Monitoring and Forecasting). Monitoring and Forecasting merupakan akhir dari sebuah rangkaian panjang dalam proses planning and budgeting, dimulai dari tahap penentuan strategic planning, kemudian menentukan target setting, lalu masuk pada tahap operational planning, dan terakhir adalah tahap monitoring and forecasting.

Strategic planning merupakan sebuah proses perencanaan dilakukan oleh top management dan middle management PT BNI (Persero), Tbk. untuk mencapai tujuan yang lebih luas (wide) yang berisi susunan sistematik mengenai langkah yang akan dilakukan di masa depan. Dengan didasarkan pada pertimbanganpertimbangan yang seksama atas potensi, faktor-faktor eksternal dan pihak-pihak yang berkepentingan dalam rangka mencapai suatu tujuan tertentu. Unit yang melakukan fungsi ini adalah Divisi REN yang bekerjasama dengan Divisi PKU dan CMO. Ketiga unit tersebut masuk di dalam komite planning and budgeting, dimana komite ini melakukan secara periodik (bulanan, triwulanan, semesteran dan tahunan) dengan agenda updating kinerja salah satunya.

Sejak 2006 PT BNI (Persero), Tbk. telah melakukan pengukuran kinerja dengan hanya dua perspektif yaitu financial dan operasional. Hingga sampai dengan saat ini pengukuran kinerja berbasis Balance Scorecard dituangkan dalam enam perspektif yaitu financial, growth, risk, customer, employee, dan process. Pengukuran kinerja saat ini, dilakukan pada enam level organisasi yaitu BNI wide, sektoral, divisi, wilayah, cabang, dan sentra. Sedangkan untuk level kantor layanan dan kantor kas masih dalam proses pengembangan. Dengan pengembangan enam perspektif dan pengukuran seluruh level, diharapkan pengukuran kinerja menjadi lebih berimbang, lebih objektif dan linkage. Dengan 7 tahun pengalaman, menjadikan pengukuran kinerja menjadi tools bagi unit dalam mencapai sasaran yang telah ditetapkan diawal tahun, juga menjadikan pengukuran kinerja menjadi lebih objektif dan transparan.

Sebelum 2011, pengukuran kinerja hanya dilakukan pada level divisi ke bawah, sedangkan level direktur sektor sebagai unit tertinggi PT BNI (Persero), Tbk. belum dilakukan pengukuran dengan metode yang sama. Akan tetapi sejak 2011, unit direktur sektor juga ikut diukur kinerja dengan cara yang sama dengan unit di bawahnya. Dengan penetapan KPI secara top-down dan sebaliknya di seluruh level organisasi PT BNI (Persero), Tbk., maka dapat dipastikan bahwa KPI-KPI yang dipilih telah selaras dengan Corporate Strategy, RBB yang dapat mendorong kinerja yang bersifat sustainable. KPI dalam ditetapkan dan diturunkan dari tujuan strategis bank wide dari level sektor, unit, sub unit, serta individu. Oleh karena itu setiap KPI harus mencerminkan tujuan strategis yang telah ditetapkan dan harus terdapat kesesuaian (alignment) dengan struktur dan fungsi organisasi, baik secara vertikal maupun horizontal.

Sementara beberapa hambatan yang terjadi hingga saat ini yang dapat diuraikan seperti designing KPI. KPI-KPI yang didesain saat ini, banyak yang masih belum sesuai dengan arti Key Performance Indikator itu sendiri, dimana Performance Indikator (PI) yang dipilih untuk menjadi pengukuran kinerja unit adalah yang benar-benar kunci utama atau pokok. Sedangkan beberapa PI yang kurang tepat untuk dijadikan KPI dapat dijadikan KPI Individu, guna mengukur kinerja per masing-masing individu. Selain itu, linkage KPI antar satu unit dengan unit lain, antara unit dengan sub unit di bawahnya harus dijaga, hal ini berguna agar sasaran strategis (target) besaran bersama dapat dicapai karena KPI yang sama dan searah.

Target setting dari tahun ke tahun juga masih dilakukan secara terpusat oleh Divisi PKU. Hal ini dapat menyebabkan target yang diberikan tidak sesuai dengan kondisi sebenarnya seperti potensi pasar, sasaran strategis dari masing-masing unit, perubahan kondisi makro dan mikro ekonomi yang terjadi di tengah tahun dimana dibutuhkan sebuah perubahan target secara cepat dan lain sebagainya. Pemahaman yang terbatas Divisi PKU dapat menyebabkan satu unit dapat terjadi over target, sedangkan unit lain under target. Untuk mengatasi hal ini, Divisi PKU melakukan alokasi pembagian target secara bertahap terhadap beberapa pos mata anggaran, khususnya alokasi Operating Expenses (OPEX), hal ini tidak sesuai dengan konsep planning and budgeting dimana seluruh target dialokasikan diawal tahun.

Kemudian pembobotan (weighting) yang apabila pemilihan KPI sudah tidak dapat dijadikan pembeda antara satu unit dengan unit yang lain dikarenakan mereka berada dalam satu rantai proses bisnis. Maka untuk membedakan adalah dengan melakukan pemberian bobot yang berbeda pada KPI-KPI-nya. Misalnya, 
antara unit yang menangani bisnis dengan resiko, masing-masing dari unit tersebut harus sama-sama memiliki KPI Loan Expansion dan KPI New NPL dan Pra NPL dengan bobot yang berbeda. Unit bisnis mempunyai bobot KPI Loan Expansion lebih besar dibandingkan unit resiko. Sedangkan untuk KPI New NPL dan Pra NPL, unit yang menangani resiko memiliki bobot lebih besar dibandingkan dengan unit bisnis.

Setiap penerapan strategi selalu saja mempunyai kendala yang harus dihadapi, tidak terkecuali terhadap penerapan Balance Scorecard di dalam PMS PT BNI (Persero), Tbk. Salah satu faktor kegagalan terbesar adalah kegagalan strategis. Untuk mempertahankan kinerja perseroan agar tetap berjalan dengan baik walaupun perubahan terus terjadi seperti perubahan organisasi, perubahan proses bisnis dan lain-lain, diperlukan serangkaian strategi yang tepat dan terencana. Walaupun demikian, strategi yang indah belum menjamin kinerja yang baik, karena sekedar "memiliki strategi" saja tidak memecahkan masalah.

Berdasarkan hasil penelitian yang dilakukan oleh Robert S. Kaplan dan David P. Norton, diketahui bahwa hanya $10 \%$ dari perusahaan-perusahaan di Amerika Serikat yang dapat mengeksekusi strategi dengan baik. Dari studi itu pula, evaluasi terhadap PMS sebagai pengukuran kinerja PT BNI (Persero), Tbk. mencoba untuk dibahas satu persatu, yaitu:

1. Hambatan pada visi. Hambatan ini terjadi karena kurangnya sosialisasi dari visi yang telah dibangun. Dengan struktur organisasi yang besar yaitu terdiri dari 11 direksi, 38 divisi, 14 kantor wilayah, 14 Head of Business Banking, 14 Head of Network and Services, 14 Head of Consumer and Retail, 168 cabang, 20 Sentra Kredit Menengah, 51 Sentra Usaha Kecil, 12 Sentra Kredit Konsumer, 5 cabang luar negeri, 912 kantor layanan dan 345 kantor kas dengan total karyawan sebanyak 25.000 dan jaringan tersebar di seluruh wilayah Indonesia, menjadi pekerjaan besar bagi manajemen perusahaan untuk membuat setiap karyawan mempunyai pemahaman yang sama terhadap visi Bank BNI.

2. Hambatan pada pelaku. Seluruh karyawan PT BNI (Persero), Tbk. yang berjumlah lebih dari 25.000 orang di semua jenjang dalam struktur organisasi adalah pelaku dari visi, misi dan strategi yang telah dibangun. Untuk memotivasi mereka agar efisien dan efektif dalam menerapkan strategi, perseroan penting untuk mengaitkan keberhasilan penerapan strategi tersebut dengan insentif karyawan, misalnya ke perhitungan bonus dan remunerasi pegawai. Hal ini sangat penting mengingat strategi yang rencanakan dengan baik, merupakan setengah keberhasilan yang dicapai. Penerapan strategi ini dilakukan setiap tahun, akan tetapi dalam implementasi strategi tersebut tidak dijabarkan ke setiap level organisasi hingga ke masing-masing individu pegawai.

3. Hambatan pada manajemen. Kendala ini wajar bila manajer terlalu banyak menghabiskan waktunya pada kegiatan operasional rutin, tetapi sangat disayangkan bila mereka tidak punya waktu sedikitpun untuk membahas strategi perusahaan. PT BNI (Persero), Tbk. yang juga berorientasi pada profit, lebih sering membahas strategi hanya pada aspek finansial saja seperti pencapaian laba, ekspansi dana dan kredit dan lain sebagainya. Sedangkan aspek customer, resiko, kepuasan pegawai, dan proses yang excellent sering diabaikan. Mengingat setiap perspektif menjadi pendorong tercapainya hasil akhir finansial, maka setiap aspek tersebut haruslah dianggap sama pentingnya.

4. Hambatan sumber daya. Hambatan terakhir dalam hal ini adalah modal. Studi menunjukkan bahwa 60\% dari organisasi tidak mengaitkan anggaran dengan strategi. PT BNI (Persero), Tbk. sangat perlu mengaitkan anggaran karena setiap pelaksanaan strategi memerlukan biaya. Sebagai salah satu komponen yang dialokasikan pada saat target setting, alangkah baiknya setiap anggaran biaya yang dikeluarkan harus didasarkan strategi inisiatif yang dituangkan dalam enablers' yang jelas dan aplikatif. Artinya, setiap rupiah yang dikeluarkan harus jelas berapa benefit-nya.

Sebagai salah satu dari empat nilai budaya kerja PT BNI (Persero), Tbk. yaitu perbaikan tiada henti (Continuous Improvement) yang dijadikan pedoman setiap insan perseroan dalam menjalankan aktifitas pekerjaan sehari-hari, pengukuran kinerja juga melakukan beberapa perbaikan dimaksud dengan melihat beberapa peluang perbaikan Opportunity for Improvement (OFI) yaitu perubahan perspektif PMS berdasarkan Balance Scorecard yaitu keuangan, pelanggan, proses bisnis internal, pembelajaran dan pertumbuhan telah mulai diterapkan pada pengukuran kinerja PT BNI (Persero), Tbk. walaupun hanya mengadopsi dua perspektif pada awalnya yaitu financial dan operational. Sejak 2011 pengukuran kinerja dijabarkan dalam enam perspektif yaitu financial, growth, risk, customer, employee, dan process. Modifikasi ini bertujuan agar setiap aspek yang dianggap penting saat ini terwakili di dalam pengukuran kinerja, seperti aspek resiko dan pegawai. Di masa yang akan datang, pemilihan perspektif dapat diubah berdasarkan tujuan dan fokus bisnis perusahaan, apakah akan ditambah atau sebaliknya. 
Kedua adalah level pengukuran kinerja. Saat ini, pengukuran kinerja PMS baru dilakukan pada lima level organisasi PT BNI (Persero), Tbk. yaitu BNI wide, sektoral, divisi, wilayah, cabang dan sentra. Kondisi sebelumnya adalah, pengukuran kinerja PMS hanya di tiga level yaitu divisi, wilayah, cabang, dan sentra. Hal ini menyebabkan terputusnya informasi strategi dan rencana kerja dari level teratas dengan level di bawahnya, karena belum tertuang dalam KPI-KPI dalam PMS. Dengan telah diukurnya kinerja level 1 sampai dengan level 5, diharapkan linkage yang bersifat bottom up dan sebaliknya dapat terjadi. Kondisi ini lebih baik lagi jika pengukuran kinerja level kantor layanan (KLN) dan kantor kas (KK) dapat terwujud, mengingat sebagian besar outlet Bank BNI (1257 outlet) adalah KLN dan KK. Sehingga arah strategi level atas dapat diikuti hingga level terbawahnya.

Terakhir adalah penerapan scoring methodology. Dalam melakukan perhitungan scoring dalam PMS adalah dengan membandingkan antara pencapaian realisasi (aktual) dengan target yang sudah ditetapkan sebelumnya. Terdapat dua pendekatan dalam membandingkan antara pencapaian aktual dengan target yang sudah ditetapkan sebelumnya. Beberapa upaya perbaikan yang telah dan akan dilakukan untuk scoring methodology di PMS di antaranya perhitungan scoring methodology ini disesuaikan dengan kondisi dan fokus bisnis perseroan pada periode tertentu dan KPI-nya. Artinya bisa saja scoring terhadap satu fokus bisnis, misal KPI Fee Base Income diberi score 5 (tertinggi) apabila mencapai target. Sedangkan untuk KPI lain karena bukan merupakan fokus utama bisnis, hanya diberi score 4 atau 3 apabila mencapai target. Begitu juga perlakuan scoring methodology yang berbeda terhadap special driver yang diukur oleh pihak ketiga, seperti KPI Survey MRI, KPI Beban Resiko Operasional, dan KPI yang pencapaian terdapat range maximum dan minimum achievement.

Demikian juga perubahan sistem scoring telah diubah dari yang bersifat district dalam rentang $1-5$ (tahun 2006-2010) menjadi bersifat kontinyu (0,01 dan seterusnya hingga score maksimal 5). Hal ini menjadikan pemberian score lebih rigid sesuai dengan pencapaian hasil kinerja KPI. Artinya setiap rupiah diukur dengan lebih persisi dan fair. Upaya perbaikan di masa datang masih dapat dilakukan dengan memperlebar range score menjadi lebih lebar, misalnya dari 0,01 hingga 7. Hal ini dilakukan agar tiring pencapaian kinerja lebih luas, unit mana yang berada dengan kategori sangat memuaskan hingga yang kurang.

Sejak 2010 telah diterapkan score minus sebagai penalty bagi unit-unit atas pencapaian kinerja lebih rendah dari baseline awalnya (tahun sebelumnya). Tujuan score minus ini awalnya sebagai signal bagi unit terhadap pencapaian kinerja. Spirit ini masih dapat dikembangkan dengan membuat sistem scoring minus yang lebih detail (kontinu), sebagaimana yang telah diterapkan oleh scoring yang positif. Saat ini score minus hanya berupa angka minus 1 , bisa saja ke depan diberikan score $-0,01$ sampai dengan range terbawah $(-5$ atau -7$)$.

Kemudian transformasi dari product centric menjadi customer centric bagi PT BNI (Persero), Tbk. telah melakukan perubahan proses bisnis yang disesuaikan dengan tuntutan pasar yaitu dari product oriented (product centric) menjadi lebih fokus terhadap pelanggan (customer centric). Perubahan ini menyebabkan munculnya unit-unit baru yang lebih spesifik dalam melakukan fungsinya. Perubahan ini harus diikuti juga dengan pengukuran kinerja, yaitu dengan memilih KPI yang lebih customer oriented, sehingga diharapkan setiap unit diukur sesuai fungsi dan tanggung jawabnya. Lalu ada pula perbaikan governance PMS. Dimana governance dijadikan sebagai detailing dari Standard Operational Procedure (SOP). Perubahan sangat dituntut guna mengikuti perkembangan situasi dan kondisi selama proses pengukuran kinerja.

Beberapa hal yang dianggap penting untuk di update di dalam governance antara lain simplifikasi proses endorsement KPI, target dan bobot dari forum Rapat Direksi (RADISI) jadi hanya sampai forum Performance Management Committee (PMC) saja. Demikian beberapa flow activity yang dapat dilaksanakan dengan lebih singkat dalam hal proses designing KPI dan validasi perubahan KPI, target, bobot dari forum RADISI, atau dengan sistem sirkulasi ke segenap direktur sektor, jadi hanya sampai forum PMC saja.

\section{KESIMPULAN DAN SARAN}

Berdasarkan hasil penelitian dan pembahasan dapat ditarik beberapa kesimpulan, yaitu:

1. Score akhir PT BNI (Persero), Tbk. adalah 3,85, dengan rentang -1 sampai dengan 5. Artinya telah berhasil mencapai target di berbagai sisi perspektif. Walaupun pencapaian kinerja ini belum diperoleh dari keberhasilan dari masing-masing perspektif yaitu risk, customer, employee, financial, process, dan growth akan tetapi ini merupakan sebagai sebuah keberhasilan tersendiri di tengah persaingan 
perbankan yang semakin ketat. Big pictures ini dapat dijadikan bahan evaluasi dan perbaikan untuk tahun-tahun mendatang dengan strategi-strategi yang lebih mengena.

2. Beberapa faktor pendukung pencapaian kinerja PT BNI (Persero), Tbk. sampai dengan saat ini adalah proses pelaksanaan planning and budgeting yang terintegrasi dilakukan oleh tiga divisi terkait, pengalaman yang panjang dalam mengukur kinerja sejak 2006 hingga saat ini, dan dukungan dari top management berupa keterlibatan langsung sejak awal proses PMS hingga finalisasi hasil PMS. Sedangkan faktor-faktor penghambat yang masih harus dilakukan upaya perbaikan adalah designing KPI yang harus dapat disesuaikan dengan fungsi organisasi, target setting masih dilakukan dengan cara sentralisasi untuk level divisi, dan pembobotan (weighting) masih memerlukan perimbangan yang lebih tepat antara unit-unit dengan fokus yang berbeda.

Beberapa hambatan terkait dengan strategi bisnis antara lain hambatan pada visi yang tidak dapat dijabarkan secara detail ke dalam corporate plan hingga operational plan, kurang pemahaman pelaku (user) terhadap kinerja itu sendiri, manajemen PT BNI (Persero), Tbk. yang mempunyai kepentingan yang bersifat strategis dapat menjadikan pengukuran tidak objektif dan terakhir adalah sumber daya yang terbatas atau belum dimanfaatkan sesuai dengan strategi inisiatif dan rencana kerja.

3. Beberapa upaya perbaikan yang dapat dilakukan guna mendapatkan pengukuran kinerja yang lebih baik antara lain perubahan perspektif PMS yang mengikuti fokus bisnis dari perusahaan, tidak terpaku pada teori dengan empat perspektif, bisa saja enam (saat ini) atau lima (di masa yang akan datang). Level pengukuran kinerja hampir sempurna yaitu level BNI wide (Level 1) hingga cabang dan sentra (level 5). Untuk ke depan perlu diupayakan percepatan pengukuran kinerja untuk level KLN dan KK (level 6), mengingat hampir sebagian besar outlet Bank BNI ada pada level tersebut. Penerapan scoring methodology perlu secara terus menerus dilakukan perubahan, disesuaikan dengan sasaran strategis yang ingin ditekankan pada suatu titik bisnis, seperti peningkatan fee base income atau beban CKPN. Transformasi dari product centric menjadi customer centric harus disikapi dengan perubahan cara mengukur kinerja unit, hal ini dikarenakan munculnya unit-unit dengan fungsi-fungsi baru. Perbaikan governance PMS harus dapat mengikuti perubahan dari tahun ke tahun, akibat pergeseran arah dan fokus bisnis, maka beberapa rule yang dijadikan guiding principle dalam PMS harus juga disesuaikan.

Dari beberapa permasalahan yang dihadapi PT BNI (Persero), Tbk. dalam melakukan pengukuran kinerja unit, berikut beberapa saran yang berguna untuk perbaikan perusahaan di masa yang akan datang:

a. Proses planning and budgeting yang belum sempurna akibat pelaksanaan dilakukan di divisi-divisi terpisah dapat diatasi dengan mengoptimalkan komite Performance Management Committee (PMC) baik di level teknis maupun level pemimpin. Dengan melakukan pertemuan secara rutin baik itu bulanan, triwulan, semesteran dan tahunan isu-isu yang muncul yang dapat menjadi batu sandungan dalam upaya mencapai target yang telah ditentukan dapat diatasi atau diminimalisir.

b. Setiap level unit yang diukur sebaiknya mengikuti governance dan guiding principles yang telah ditentukan dan disepakati di depan. Hal ini guna menjaga integritas dan terjaganya azas fairness yang harus dijunjung oleh semua divisi. Apabila terdapat hal-hal yang menghambat tercapainya sebuah sasaran strategi inisiatif (target) akibat adanya force major internal seperti perubahan kebijaksanaan yang diputus oleh manajemen tertinggi PT BNI (Persero), Tbk. di tengah tahun berjalan, maka terbuka peluang untuk dilakukan professional adjustment oleh direktur sektornya.

c. Pengukuran kinerja unit hanya sebuah alat ukur, dimana diharuskan tetap melakukan penyesuaian terhadap setiap perubahan yang terjadi, seperti perubahan organisasi, perubahan bisnis, dan perubahan kebijaksanaan manajemen. Fine tuning ini dimaksudkan agar PMS dapat terus update terhadap apa yang akan diukur dan bagaimana cara mengukur.

\section{DAFTAR PUSTAKA}

Budisantoso, Totok, dan Sigit Triandaru. (2006). Bank dan Lembaga Keuangan Lain. Jakarta: Salemba Empat. Edisi Dua.

Data Kinerja PMS PT Bank Negara Indonesia (Persero), Tbk. Tahun 2011 dan 2012.

Kaplan, Robert S dan David Norton. (1996). Balanced Scorecard: Translating Strategi Info Action. Boston: Harvard Business School.

Kasmir. (2003). Bank dan Lembaga Keuangan Lainnya. Jakarta: PT Raja Grafindo Persada. Edisi Enam. Mulyadi. (2005). Sistem Manajemen Strategik Berbasis Balance Scorecard. Yogyakarta: UPP AMPYKPN. Cetakan Pertama. 